\title{
STUDY ON IMPACT OF KARNATAKA INDUSTRIAL POLICY 2014-2019 ON MSME UNITS IN DHARWAD: AN EMPIRICAL EVALUATION
}

\author{
SUNILKUMAR R HIREMATH ${ }^{1} \&$ DR.V. SHARADA ${ }^{2 *}$ \\ ${ }^{1}$ Research Scholar, Karnatak University, Dharwad, Karnataka, India \\ $2^{*}$ Associate Professor, Karnatak Arts College, Dharwad, Karnataka, India
}

\section{ABSTRACT}

MSME (Micro, Small and Medium Enterprises) are the backbone of economic development in any country. In India, MSME plays a significant role in the economic and social development of the country in terms of industrial output, employment generation, export etc. It fosters entrepreneurship and generates largest employment opportunities at comparatively lower capital cost, next only to agriculture. In India, the employment investment ratio of MSME is almost seven times than that of big industries. MSME employ about $40 \%$ of total population of India. They contribute $45 \%$ of the industrial output and $40 \%$ of total exports. The central government as well as the state governments in India frames various policies to address the various problems in areas of credit, infrastructure, technology and marketing affecting the MSME. Karnataka is a state in India, ranking fifth in terms of number of registered MSME units of around 38.34 lakhs as on 2018. The state government of Karnataka introduced industrial policy 2014-2019. The policy is an umbrella of schemes offering support in form of subsidies and concessions to promote the growth of MSME. The policy addresses various issues like infrastructure support, finance, technology upgradation, marketing support, encouragement to underprivileged sections of the society, incentives and concessions. This work analyzes the effectiveness of the industrial policy 2014-2019 in three main dimensions of finance, technology and marketing support. Questionnaire feedback is collected across 100 units in different industrial segments of manufacturing and service sectors in district of Dharwad in Karnataka. Hypothesis designed to examine the satisfaction levels qualitatively are tested using Chi-Square P-Test. An insight into the effectiveness of the industrial policy 2014-2019 in three different dimensions of finance, technology and marketing support is made possible with this study. In addition, the study also measures the satisfaction levels sector wise.

KEYWORDS: Karnataka Industrial Policy 2014-19, Dharwad

Received: Feb 08, 2020; Accepted: Feb 28, 2020; Published: Nov 17, 2020; Paper Id.: IJMPERDFEB202086

\section{INTRODUCTION}

Over last decade, MSME has emerged as highly contributing sector to the inclusive industrial development of the India. MSME's have widened their domain across sectors of the economy with production of diverse range of products and services meeting the domestic and global markets needs. Karnataka is a state in southern part of India is one of India's fastest growing states, having a strong industrial base and a vibrant service sector. The State has a host of large industries ably supported by a strong base of micro, small and medium sector. Due to inherent advantages available in the State, the industry and trade sectors including the service sector are propelling the overall economic development of Karnataka. Karnataka ranks fifth among all Indian states in terms of number of enterprises as per annual report 2018-2019 of ministry of micro, small and medium enterprises with around 6\% of country wide total. The state has around 38.34 lakh registered MSME units in different sectors of agro, textiles, 
furniture, leather, metals, engineering, readymade garments etc.

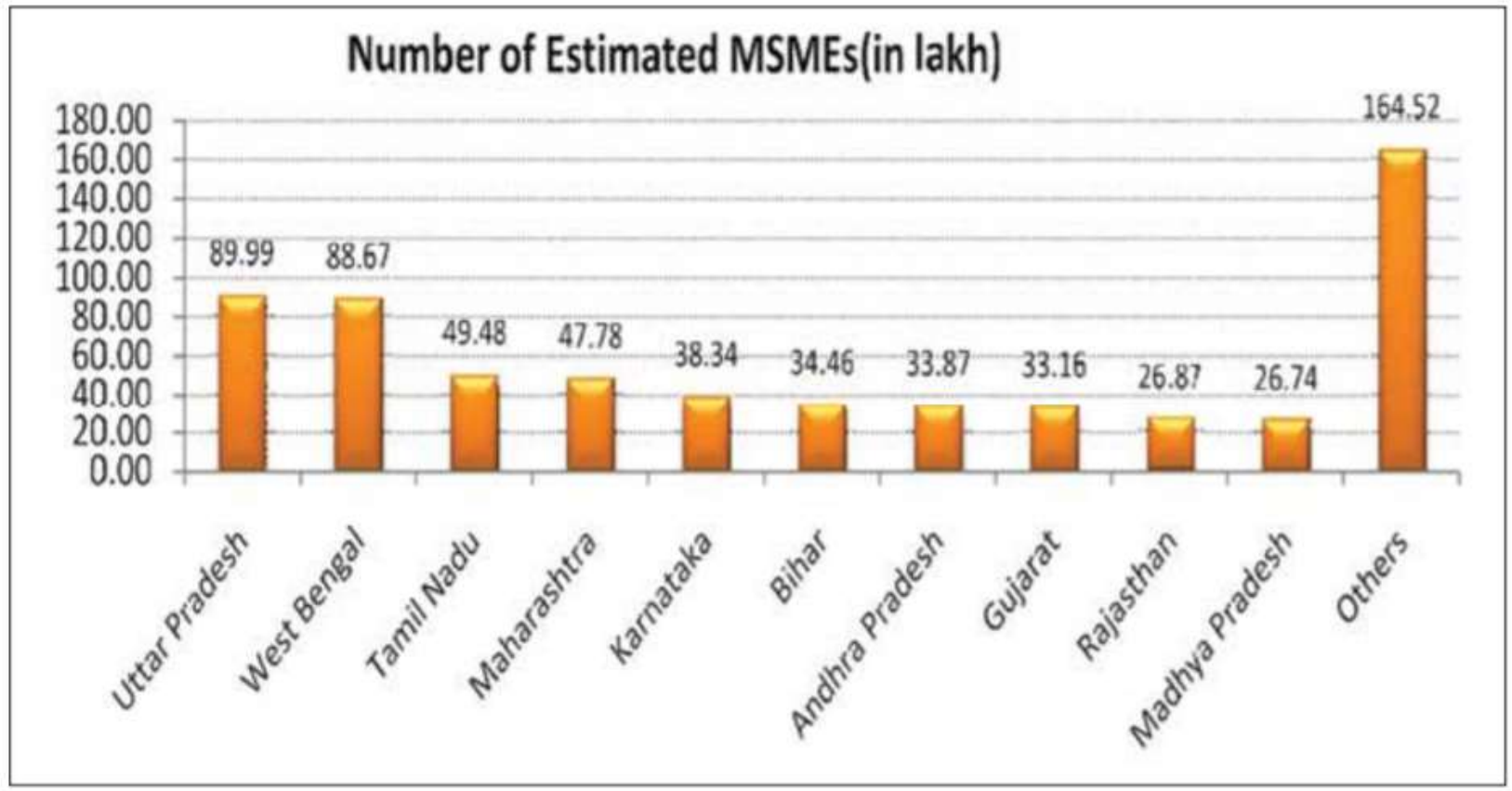

MSME in India face three major problems related to finance, marketing and technology. Inadequate finance coupled with taxation expenses is the major problem for MSMEs. Since most of the MSMEs are proprietary concern or partnership firms, their internal resources are small. The credit provided by the various institutional agencies such as banks, State Financial Corporation (SFCs) and Small Industrial Development Bank of India (SIDBI) are inadequate to meet the requirements of small units. The institutional agencies are still reluctant to advance money to small industries as they are unable to offer security guarantee required by them. The shortage of funds makes it difficult to install modern machinery, unable to buy and store required raw materials or stock of finished goods or have their own sales organization. In marketing their products, the MSMEs have to face competition from other small-scale units and also from large industries. The small units do not possess their own marketing organization. They do not have the resources and expertise to market their products effectively. Further, their products are often not standardized and of variable quality. Therefore, the MSME units suffer from a comparative disadvantage compared to large-scale units. Financial constraints compel the small units to sell their products at unremunerative prices. Many small units sell their products to large selling houses at low prices. One of the major handicaps limiting the MSME in India is the absence of latest technology to ensure quality and high rate of productivity. Most of the small-scale units use only obsolete and outdated technology and old machinery and equipment. Adoption of latest technology alone can ensure good quality and higher productivity.

To mitigate the problems of MSME and to bring balanced economic growth across the state, various exclusive industrial policies and sector specific policies like textiles, information and bio technology, aerospace, hardware etc have been adopted to facilitate setting up of enterprises, create jobs and wealth. In the latest five year industrial policy 2014-19, state government of Karnataka addresses the promotion of MSMEs by providing subsidies and concessions and various schemes to enable and encourage the growth of MSMEs. Particular attention is given to MSMEs while framing the New Industrial Policy in Karnataka (2014-19) which enables MSMEs to gain a wide range of support in forms of various schemes and concessions. The various benefits provided to MSME is grouped into three categories of finance, marketing/promotion and technology under industrial policy 2014-19 is given below 
Table 1: MSME provisions in Karnataka Industrial Policy 2014-19

\begin{tabular}{|c|c|}
\hline Finance & $\begin{array}{l}\text { Investment Promotion subsidy } \\
\text { Exception from stamp duty } \\
\text { Concessional Registration charges } \\
\text { Reimbursement of Land conversion fee } \\
\text { Exception from entry tax, APMC Cess } \\
\text { Subsidy for Setting up Effluent Treatment Plant (ETP) } \\
\text { Manufacturing MSMEs } \\
\text { Interest Subsidy for Micro Enterprises } \\
\text { Exemption from Electricity duty }\end{array}$ \\
\hline Marketing/Promotion & $\begin{array}{l}\text { Price preference of } 15 \% \text { for MSME for government } \\
\text { purchases } \\
\text { Product exhibition shows } \\
\text { Urban Haat Scheme }\end{array}$ \\
\hline Technology & $\begin{array}{l}\text { Interest subsidy on Technology up gradation loan. } \\
\text { Subsidy for ISO,BIS series certification } \\
\text { Subsidy for Patent registration } \\
\text { Subsidy for Technology adoption } \\
\text { Subsidy for Technology business Incubation centre. }\end{array}$ \\
\hline
\end{tabular}

The government of Karnataka has released funds up to a total of 20,959.4 million rupees from 2014 to 2019 under industrial policy 2014-19.

Table 2: Funds Released under Karnataka Industrial Policy 2014-19

\begin{tabular}{||l|c|c|c|c|c||}
\hline \multirow{2}{*}{ Schemes } & \multicolumn{5}{|c|}{ Funds released Financial year-wise } \\
(in Rupees million)
\end{tabular}

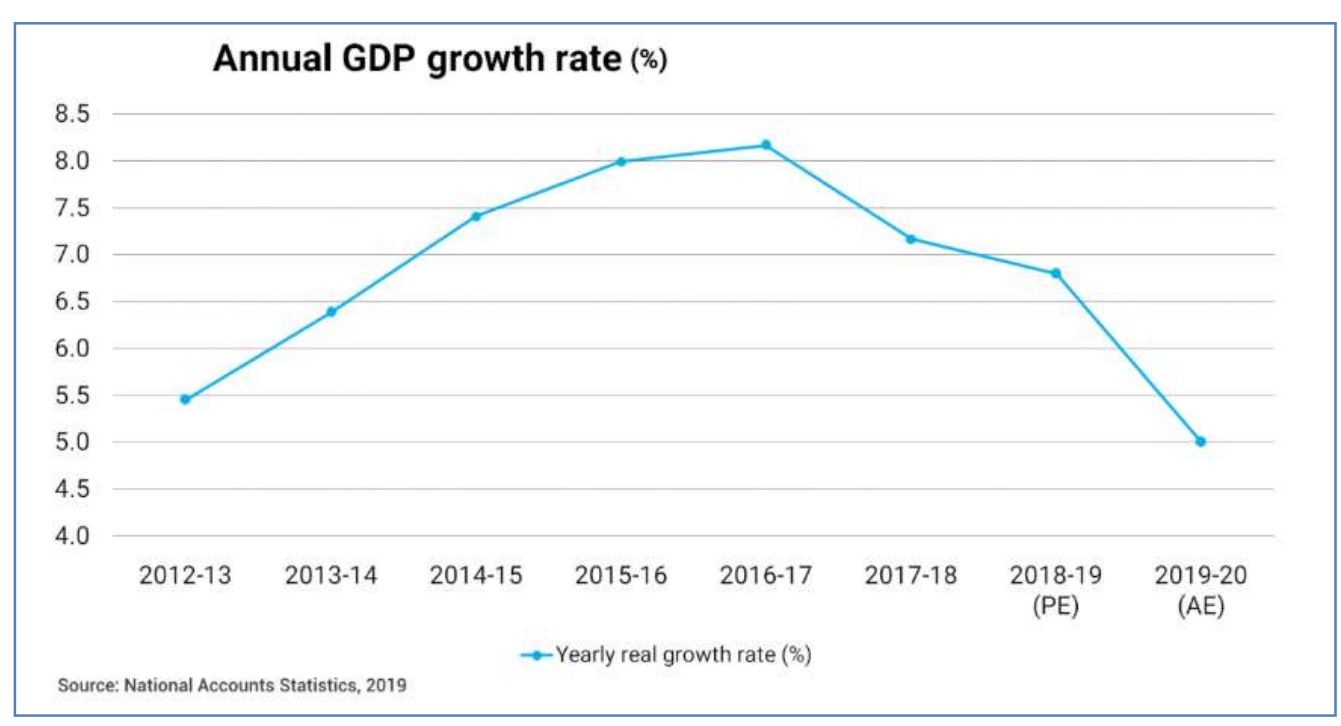

Figure 1: Indian GDP Statistics

There has been economic slowdown in India due to various global and local factors from year 2016 with GDB 
falling from $8.1 \%$ to $5 \%$ in 2019. This fall down has affected the MSME sectors in a big way and MSME expectations on government policies for their survivability has increased. The economic slowdown has created additional stress on MSME due to shrinking demand. But this work restricts itself to analyzing the effectiveness of industrial policy 2014-19 alone, filtering out the impact of economic slowdown on the study.

\section{SURVEY}

Authors in [1] analyzed the problems faced by MSMEs in selected districts of Himachal Pradesh. The effects of policies are compared before and after 2005 using questionnaire analysis. Statistical tools like ratio analysis, one way ANOVAs, Chi-Square test and Factor analysis are used to analyze the data collected and infer logical conclusions. The study identified the three financial hindrances for MSME - inadequate financing by the banks, high collateral requirements and cumbersome process. Authors in [2] analyzed the problems in Indian coir industry due to technology lag. With increasing globalization, Indian coir industry faces stiff competition from neighboring countries in exports and lags behind the rivals. The main reason being lack of use of updated technology. Lack of updated technology reduce the MSME potential, lower the product demand and lower profit margin. The performance of Indian MSMEs post and pre liberalization is analyzed in [3]. Performance variables for measuring the effectiveness of MSME is designed and compared between post and pre liberalization. The study also examined the inter-relationship between among the performance variables plus the functional relationship between the variables. Inter-relationship between the variables is found using correlation coefficient and degree of functional relationship is found using multiple regression with ordinary least square. Authors in [4] studied the characteristics of MSME in rural villages of Assam and various finance related problems hindering their growth. The study was done to identify the gaps related to finance in Prime Minister's Employment Generation Programme (PMEGP). Primary data for study is obtained through questionnaire presented to MSME units. Statistical tools like Pearson Chisquare, likelihood ratio, Fishers exact test were used. It is found that MSME was not satisfied with amount sanctioned and difficulties with borrowing. Authors in [5] analyzed the effectiveness of Micro, Small and Medium Enterprise Development (MSMED) Act, 2006. The effectiveness of scheme is measured in terms of average growth rate, average employment generation rate and exports. The study revealed that apart from increase in employment generation rate, the growth rates in other parameters were not encouraging post MSMED Act 2006. Authors in [6] presented a critical analysis on assistance of public sector banks to MSME's and its effect on their performance. Structured questionnaire response collected from the MSME units is used as primary data. Hypothesis is framed on correlation between MSME growth and financial assistance provided by the public sector banks and tested using Chi-Square test. Export performance of the MSMEs and their determinants is studied in [7]. Government scheme is on determinant considered in this study. Tobit model is used in this study.

From the survey, there has been no previous works related to assessing the impact of government welfare schemes in all three dimensions of personal, social and financial scales across different age groups. This multi dimensional study is necessary as the different welfare schemes does not have same impact across all age groups and the identification of satisfaction levels in each age group is necessary to fine tune the welfare schemes. Authors in [8] analyzed the satisfaction level MSME towards implementation of GST in India. The study was conducted across 100 companies in Bangalore, Mysore and Tumkur district through a structured questionnaire. One sample $t$ test was used to analyze the impact of GST on MSME. Both positive and negative impacts were observed. Removal of composition burden, input tax credit, increasing the threshold limit exemptions, etc was found to be positive impacts. More capital requirement s and compliance cost was 
found to be negative impacts. Authors in [9] identified the problems in marketing for MSMEs. The study identified the problems in adopting internet marketing and e-commerce by the MSMEs. Adoption of internet marketing and e-commerce could help MSME to gain competitive advantage over rivals. The study also indentified the low adoption of internet marketing among Indian MSMEs. Authors in [10] studied various problems in raising finance by the MSMEs in Nagpur city. The study identified lack of credit history is being a main barrier in financing to micro enterprises. The government schemes must compensate for this problem by providing a security to first generation entrepreneurs. Authors in [11] studied the regulatory and operational problems faced by MSME by touching on the present government policies and providing policy recommendations. The study was conducted with MSMEs located in industrial areas of New Delhi. The study identified the major problems faced by MSME related to finance marketing, government regulations, managerial incompetence, infrastructure, competition, macroeconomic instability, technology upgradation and lack of skilled labour. Finance, marketing and lack of skilled manpower were identified as biggest problem in both manufacturing and service sector MSMEs. Authors in [12] analyzed the performance of MSME in relationship to government policies in India. The analysis was done at a macro level based on the secondary data released in annual reports. The effectiveness of the policy was measured in terms of number of registered MSME and market value of assets of MSME. The analysis inferred a positive impact of MSMED Act, 2006 on growth of small industries. Authors in [13] analyzed the growth and performance of MSME in Industrial estate of Harihara in the Davangere district. The study identified the problems of MSME in the industrial estate of Harihara as finance, poor management and accounting practices. Authors in [14] tried to establish the relation between the factors under the utility of loan, utilisation of fund, and capital formation in the MSMEs. The primary data for the research was collected from entrepreneurs of the two selected districts East and West Medinipur of West Bengal state who have taken loan from public sector banks. The study applied exploratory factor analysis, confirmatory analysis, multiple regressions, and path analysis of the structural model. Authors attempted to build a model on the relation between utility of loan service (ULS), utilization of fund (UF), and capital formation (CF) across the enterprises. Authors in [15] studied the growth and problems of MSME in Shivamogga district of Karnataka. The study indentified the three main problems facing the MSME were inadequate finance, inefficient manpower and marketing issues. The study is based on secondary data collected from books, journals and newspapers.

\section{RATIONALE FOR THE STUDY}

As we surveyed there were not much existing works for analyzing the effectiveness of Karnataka industrial policy 2014-19 from the perspective of the MSME. Also the current methods for analyzing the effectiveness of government schemes were based on parameters like employment ratio, number of registered units, average growth rate etc gathered from secondary data. The performance parameters are on a macro level, without any scope for analyzing the satisfaction level on each of the provisions of the scheme at a fine grained level against multiple dimensions of problems faced by the MSME. Also analysis of effectiveness using the above said parameters alone becomes erroneous as many of the registered units are not in operation and got shutdown due to many macro economic problems in India after 2016. This work bridges this gap by analyzing the satisfaction level of schemes at a fine grained level in three dimensions of finance, marketing and technology.

\section{OBJECTIVE OF THE STUDY}

Following are the objectives 
- To study the satisfaction level of MSME towards the provisions of Karnataka Industrial Policy 2014-19 in three dimension of finance, marketing and technology.

- $\quad$ To study the homogeneity of satisfaction level across manufacturing and service sectors MSME.

- Analysis of satisfaction level at fine grained level on different provisions of Karnataka Industrial Policy 2014-19 specific to MSME.

\section{RESEARCH HYPOTHESIS}

The research tests following hypothesis

Table 3: Hypothesis

\begin{tabular}{|l|l|l|}
\hline S.NO & \multicolumn{1}{|c|}{ Null Hypothesis } & \multicolumn{1}{c|}{ Alternate Hypothesis } \\
\hline 1 & $\begin{array}{l}\text { MSMEs are satisfied with the financial concessions } \\
\text { and incentives of Karnataka Industrial Policy 2014- } \\
19\end{array}$ & $\begin{array}{l}\text { MSMEs are not satisfied with the financial } \\
\text { concessions and incentives of Karnataka Industrial } \\
\text { Policy 2014-19 }\end{array}$ \\
\hline 2 & $\begin{array}{l}\text { MSMEs are satisfied with the } \\
\text { marketing/promotions assistance provided in } \\
\text { Karnataka Industrial Policy 2014-19 }\end{array}$ & $\begin{array}{l}\text { MSMEs are not satisfied with the } \\
\text { marketing/promotions assistance provided in } \\
\text { Karnataka Industrial Policy 2014-19 }\end{array}$ \\
\hline 3 & $\begin{array}{l}\text { MSMEs are satisfied with the technology up } \\
\text { gradation assistance provided in Karnataka } \\
\text { Industrial Policy 2014-19 }\end{array}$ & $\begin{array}{l}\text { MSMEs are not satisfied with the technology up } \\
\text { gradation assistance provided in Karnataka Industrial } \\
\text { Policy 2014-19 }\end{array}$ \\
\hline 4 & $\begin{array}{l}\text { The satisfaction level homogenous across } \\
\text { manufacturing and service sector }\end{array}$ & $\begin{array}{l}\text { The satisfaction level is not homogenous across } \\
\text { manufacturing and service sector }\end{array}$ \\
\hline
\end{tabular}

\section{VI.METHODOLOGY}

This research study is explorative in nature. It involves both qualitative and quantitative data analysis. To research the satisfaction level of Karnataka industrial policy 2014-19, Dharwad district of Karnataka is selected as case study for investigation.

Dharwad district is situated in the Western sector of the northern half of Karnataka State with a total registered MSME unit of 900 distributed across various sectors in manufacturing and service sectors as below. 


\begin{tabular}{|c|c|c|c|c|}
\hline \multirow{2}{*}{$\begin{array}{c}\text { NIC CODE } \\
\text { No. }\end{array}$} & TYPE OF & NUMBER & INVESTMENT & \multirow[t]{2}{*}{ EMPLOYMENT } \\
\hline & INDUSTRY & OF UNITS & (Lakn Rs.) & \\
\hline 20 & Agro based & 40 & 80.27 & 209 \\
\hline 22 & Soda water & 3 & 40.27 & 35 \\
\hline 23 & Cotton textile & 60 & 84.85 & 140 \\
\hline 24. & $\begin{array}{l}\text { Woolen, silk \& artificial Thread } \\
\text { based clothes. }\end{array}$ & 30 & 20.00 & 60 \\
\hline 25. & Jute \& jute based & 0 & 00 & 00 \\
\hline 26. & $\begin{array}{l}\text { Ready-made garments \& } \\
\text { embroidery }\end{array}$ & 32 & 15.20 & 75 \\
\hline 27. & Wood/wooden based furniture & 59 & 52.71 & 93 \\
\hline 28. & Paper \& Paper products & 6 & 45.47 & 32 \\
\hline 29. & Leather based & 63 & 76.99 & 215 \\
\hline 31. & Chemical/Chemical based & 22 & 85.97 & 106 \\
\hline 30. & Rubber, Plastic \& petro based & 8 & 69.72 & 27 \\
\hline 32. & Mineral based & $\begin{array}{c}\text { Not } \\
\text { Available }\end{array}$ & Not Available & Not Available \\
\hline 33. & Metal based (Steel Fab.) & 80 & 125.10 & 224 \\
\hline 35. & Engineering units & 202 & 1200.04 & 1800 \\
\hline 36. & $\begin{array}{l}\text { Electrical machinery and transport } \\
\text { equipment }\end{array}$ & 29 & 46.16 & 54 \\
\hline 97. & Repairing \& servicing & 160 & 1051.17 & 375 \\
\hline \multirow[t]{3}{*}{01.} & Others & 106 & 1156.89 & 242 \\
\hline & Kachori Making & 00 & 00 & 00 \\
\hline & & 900 & 4150.81 & 3687 \\
\hline
\end{tabular}

Figure 2: MSME Units in Dharwad

Infrastructure development focused industries like fabrication, heavy structural Engineering works, electrical and Civil Engineering Enterprises have good demand in the district and also Hotels, Motels, Hospitals, Residential Schools, Agri. Farms, and Agro-based activities like Milking, sheep rearing etc have good scope in the district. There are two clusters of automotive components (Auto Cluster Hubli-Dharwad) and readymade garments (Apparel manufacture) functioning in an effective manner in this district.

\section{Auto Cluster Hubli-Dharwad, Hubli}

\begin{tabular}{|l|l|l|}
\hline 1 & $\begin{array}{l}\text { Principal Products Manufactured } \\
\text { in the Cluster }\end{array}$ & Auto Components \\
\hline 2 & Name of the SPV & Auto Cluster Hubli-Dharwad, Hubli \\
\hline 3 & $\begin{array}{l}\text { No. of functional units in the } \\
\text { clusters }\end{array}$ & 400 units \\
\hline 4 & Turnover of the Clusters & Rupees $200 \mathrm{Cr}$. \\
\hline 5 & $\begin{array}{l}\text { Value of Exports from the } \\
\text { Clusters }\end{array}$ & Rupees $20 \mathrm{Cr}$. \\
\hline 6 & Employment in Cluster & 4000 \\
\hline 7 & $\begin{array}{l}\text { Average investment in plant \& } \\
\text { Machinery }\end{array}$ & Rupees 80 lakhs. \\
\hline 8 & Major Issues / requirement & $\begin{array}{l}\text { NO Presence of CPSU's, Central Govt. } \\
\text { agencies }\end{array}$ \\
\hline 9 & Presence of capable institutions & Yes \\
\hline 10 & Thrust Areas & Export \\
\hline 11 & Problems \& constraints & $\begin{array}{l}\text { Industrial activities not encouraged to } \\
\text { with the expectation since the location } \\
\text { is backward. }\end{array}$ \\
\hline
\end{tabular}


Readymade Garments Cluster, Hubli

\begin{tabular}{|l|l|l|}
\hline 1 & $\begin{array}{l}\text { Principal Products Manufactured } \\
\text { in the Cluster }\end{array}$ & Apparel Manufacture \\
\hline 2 & Name of the SPV & Readymade Garments Cluster, Hubli \\
\hline 3 & $\begin{array}{l}\text { No. of functional units in the } \\
\text { clusters- }\end{array}$ & 250 \\
\hline 4 & Turnover of the Clusters & $25 \mathrm{cr}$. \\
\hline 5 & $\begin{array}{l}\text { Value of Exports from the } \\
\text { Clusters }\end{array}$ & Nil \\
\hline 6 & Employment in Cluster & 1250 \\
\hline 7 & $\begin{array}{l}\text { Average investment in plant \& } \\
\text { Machinery }\end{array}$ & 1 Lakhs \\
\hline 8 & Testing needs & Yes required to carry out the testing of fabrics. \\
\hline 9 & Thrust Area & Adoption of latest technologies, \\
\hline 10 & Access to Export Market & $\begin{array}{l}\text { Since, all the units of cluster are women based } \\
\text { and micro in nature, exposure to the export } \\
\text { market is very less }\end{array}$ \\
\hline
\end{tabular}

Figure 4: Garment Cluster

Primary data is collected using a structured questionnaire administered among the MSMEs with focus of analyzing the effectiveness and satisfaction level of different provisions of Karnataka industrial policy 2014-19. The questionnaire is given in table below. The managers at MSMEs were requested to tick at appropriate places against their preferred choice for each question.

Table 4: Questionnaire

\begin{tabular}{|l|l|}
\hline \multicolumn{1}{|c|}{ Dimensions } & \multicolumn{1}{c|}{ Questions } \\
\hline Finance & $\begin{array}{l}\text { 1. Was investment promotion subsidy encouraging? } \\
\text { 2. Was exception from stamp duty helpful? }\end{array}$ \\
3. Were concessions in registration charges helpful to \\
first generation entrepreneurs? \\
4. Was the Reimbursement of land conversion quick? \\
5. Was exception from entry tax, APMC chess \\
beneficial? \\
6. Was interest subsidy useful? \\
7. Was exception from electricity duty beneficial to the \\
business?
\end{tabular}

The feedback on satisfaction levels are collected in Likert five-point scale of

A. Highly Agree (1) 

B. Moderately Agree (2)
C. Undecided (3)
D. Moderately disagree (4)
E. Strongly disagree (5)

The study is conducted across 100 MSME units in Dharwad district. The field study is conducted from March 2019 to December 2019. The current definitions of manufacturing and service enterprises which are in practice from October 2006 have been taken into account for selecting the enterprises. For a manufacturing micro enterprise, gross fixed investment in plant and machinery is up to Rs.25 lakh, and for a small enterprise above Rs.25 lakh and up to Rs.5 crore. For a service micro enterprise, gross fixed investment in equipment is up to Rs.10 lakh and, for a small enterprise above Rs.10 lakh and up to Rs.2 crore. For a manufacturing medium enterprise, gross fixed investment in plant and machinery ranges above Rs.5 crore, and up to Rs. 10 crore; and for a service medium enterprise gross fixed investment in equipment ranges above Rs. 2 crore, and up to Rs. 5 crore. The sample of 100 random units were selected based on following condition

1. The enterprise is in operation for last 3 years

2. The number of employees in enterprise is more than 10 .

3. Total investment of enterprise is more than 10 Lakh.

Manufacturing and industry related service enterprises are selected for the study. The samples were selected as below

Table 5: Sector wise Samples

\begin{tabular}{|l|l|l|}
\hline \multicolumn{1}{|c|}{ Sector } & \multicolumn{1}{c|}{ Category } & Number of units \\
\hline $\begin{array}{l}\text { Auto } \\
\text { components }\end{array}$ & Manufacturing & 40 \\
\hline Garments & Manufacturing & 30 \\
\hline $\begin{array}{l}\text { Industry } \\
\text { related } \\
\text { Services }\end{array}$ & Service & 30 \\
\hline
\end{tabular}

The proportion of sample was in proportion of distribution of the sectors in Dharwad district.

\section{RESULTS}

\section{A. Hypothesis 1}

The data collected for the questions in category of Financial is used to test the hypothesis 1 . The responses for a total of 100 samples for 7 questions is given below

Table 6: Responses for Financial category

\begin{tabular}{|l|c|}
\hline \multicolumn{1}{|c|}{ Responses } & Frequency \\
\hline Highly agree & 211 \\
\hline Moderately agree & 246 \\
\hline Undecided & 100 \\
\hline Moderately disagree & 40 \\
\hline Highly disagree & 103 \\
\hline \multicolumn{1}{|c|}{ Total } & $\mathbf{7 0 0}$ \\
\hline
\end{tabular}


Chi Square test is done on above response by combining responses categories in the Likert scale. Highly agree and Moderately agree is combined to Agree. Moderately disagree and Highly disagree are combined to Disagree. The chi square test result is given below

\begin{tabular}{|c|c|c|c|c|}
\hline Responses & Frequency & & & \\
\hline $\begin{array}{l}\text { Highly } \\
\text { agree }\end{array}$ & 211 & & & \\
\hline $\begin{array}{l}\text { Moderately } \\
\text { agree }\end{array}$ & 246 & & Actual & Expected \\
\hline Undecided & 100 & Agree & 457 & 300 \\
\hline $\begin{array}{l}\text { Moderately } \\
\text { disagree }\end{array}$ & 40 & Disagee & 143 & 300 \\
\hline $\begin{array}{l}\text { Highly } \\
\text { disagree }\end{array}$ & 103 & & & \\
\hline Total & 700 & & Chi Square value & $1.28351 \mathrm{E}-37$ \\
\hline
\end{tabular}

Figure 5: Chi-Square Test for Hypothesis 1

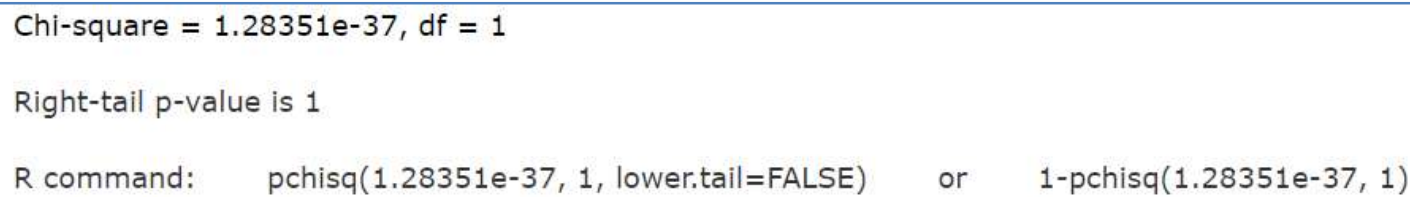

Figure 6: P value for Financial Response

The Chi square $\mathrm{p}$ value is $1>0.05$, thereby accepting the null hypothesis that "MSMEs are satisfied with the financial concessions and incentives of Karnataka Industrial Policy 2014-19” 


\section{B. Hypothesis 2}

The data collected for the questions in category of Marketing is used to test hypothesis 2 . The responses for a total of 100 samples for 3 questions are given below.

Table 7: Responses for marketing category

\begin{tabular}{|l|l|}
\hline \multicolumn{1}{|c|}{ Responses } & Frequency \\
\hline Highly agree & 30 \\
\hline Moderately agree & 40 \\
\hline Undecided & 30 \\
\hline Moderately disagree & 150 \\
\hline Highly disagree & 50 \\
\hline Total & 300 \\
\hline
\end{tabular}

Chi Square test is done on above response by combining responses categories in the Likert scale. Highly agree and Moderately agree is combined to Agree. Moderately disagree and Highly disagree are combined to Disagree

\begin{tabular}{|c|c|c|c|c|}
\hline Responses & Frequency & & & \\
\hline $\begin{array}{l}\text { Highly } \\
\text { agree }\end{array}$ & 30 & & & \\
\hline $\begin{array}{l}\text { Moderately } \\
\text { agree }\end{array}$ & 40 & & Actual & Expected \\
\hline Undecided & 30 & Agree & 70 & 135 \\
\hline $\begin{array}{l}\text { Moderately } \\
\text { disagree }\end{array}$ & 150 & Disagee & 200 & 135 \\
\hline $\begin{array}{l}\text { Highly } \\
\text { disagree }\end{array}$ & 50 & & & \\
\hline Total & 300 & & Chi Square value & 4.218 \\
\hline
\end{tabular}

Figure 7: Chi Square test for Hypothesis 2 


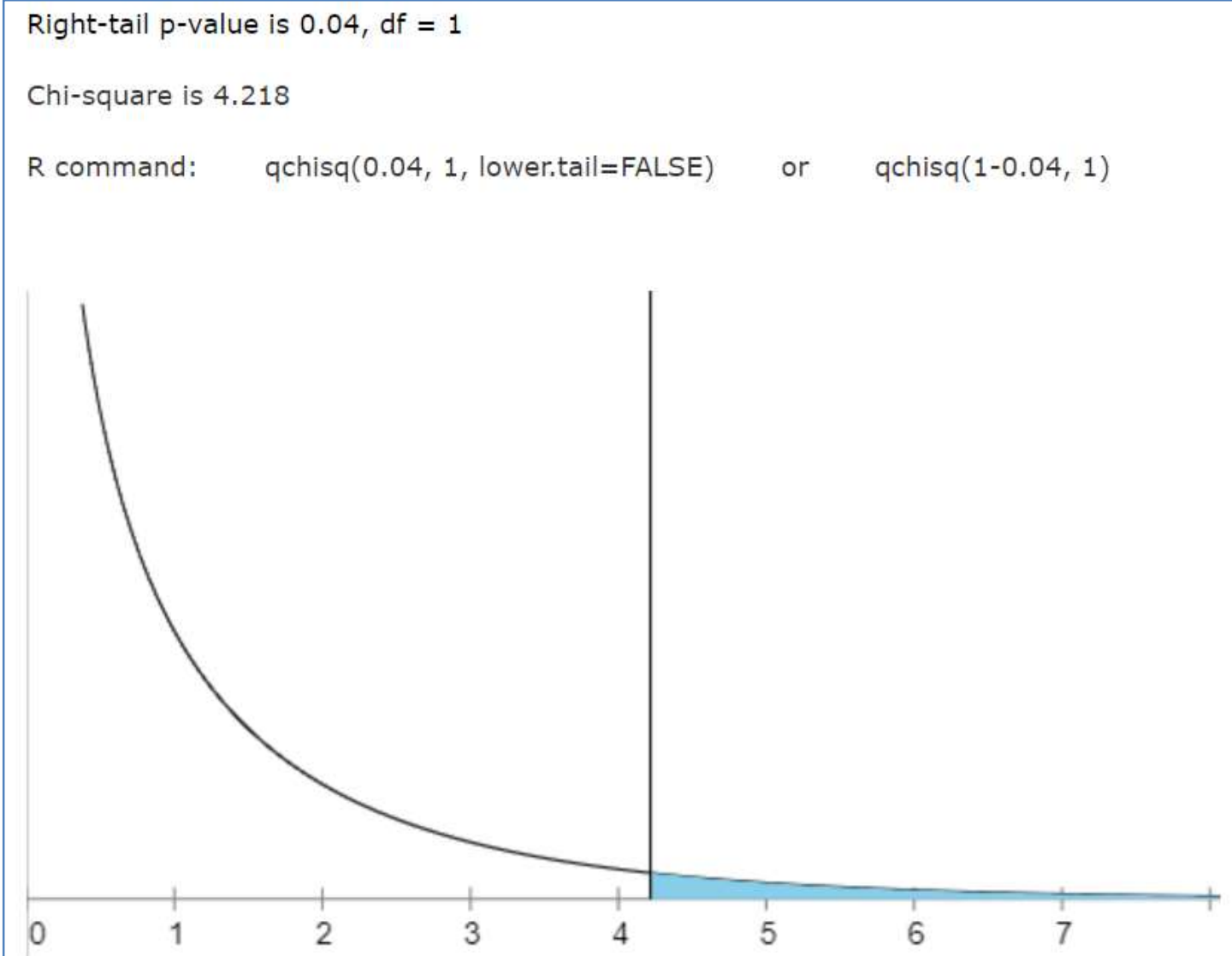

Figure 8: $P$ value for marketing category

The $\mathrm{p}$ value is $0.04<0.05$ there rejecting the null hypothesis and accepting the alternate hypothesis that "MSMEs are not satisfied with the marketing/promotions assistance provided in Karnataka Industrial Policy 2014-19”.

\section{Hypothesis 3}

The data collected for the questions in category of Technology upgradation is used to test hypothesis 3 . The responses for a total of 100 samples for 4 questions are given below.

Table 8: Responses for Technology upgradation category

\begin{tabular}{|l|l|}
\hline \multicolumn{1}{|c|}{ Responses } & Frequency \\
\hline Highly agree & 20 \\
\hline Moderately agree & 60 \\
\hline Undecided & 20 \\
\hline Moderately disagree & 200 \\
\hline Highly disagree & 100 \\
\hline Total & 400 \\
\hline
\end{tabular}

Chi Square test is done on above response by combining responses categories in the Likert scale. Highly agree and Moderately agree is combined to Agree. Moderately disagree and Highly disagree are combined to Disagree. The Chi Square test result is given below 


\begin{tabular}{|c|c|c|c|c|}
\hline Responses & Frequency & & & \\
\hline $\begin{array}{l}\text { Highly } \\
\text { agree }\end{array}$ & 20 & & & \\
\hline $\begin{array}{l}\text { Moderately } \\
\text { agree }\end{array}$ & 60 & & Actual & Expected \\
\hline Undecided & 20 & Agree & 80 & 190 \\
\hline $\begin{array}{l}\begin{array}{l}\text { Moderately } \\
\text { disagree }\end{array} \\
\end{array}$ & 200 & Disagee & 300 & 190 \\
\hline $\begin{array}{l}\text { Highly } \\
\text { disagree }\end{array}$ & 100 & & & \\
\hline Total & 400 & & Chi Square value & 4.709 \\
\hline
\end{tabular}

Figure 9: Chi Square test for hypothesis 3

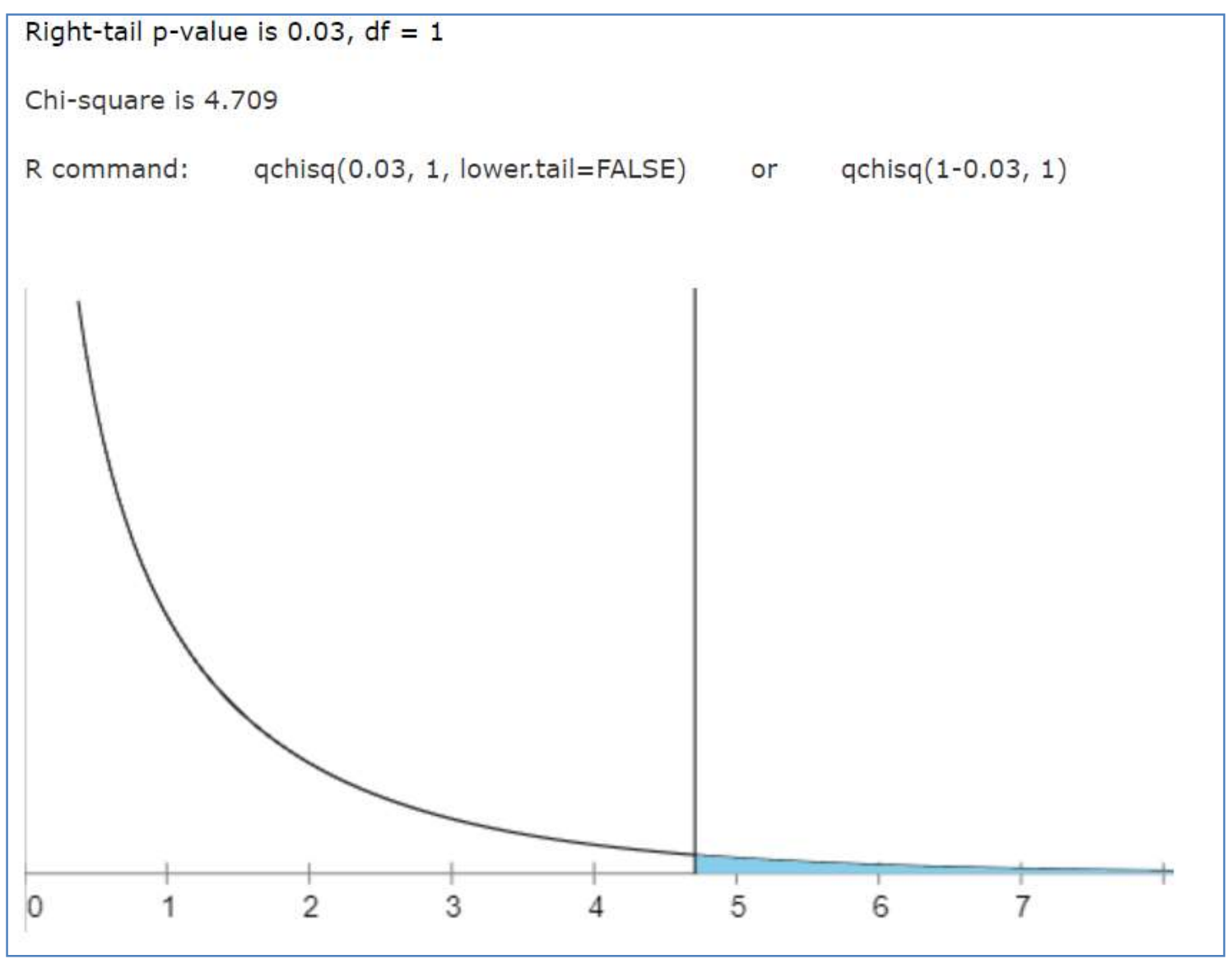

Figure 10: P value for technology upgradation category

The $\mathrm{p}$ value is $0.03<0.05$, thereby rejecting the null hypothesis and accepting the alternate hypothesis "MSMEs are not satisfied with the technology up gradation assistance provided in Karnataka Industrial Policy 2014-19”

\section{Hypothesis 4}

The response for data collected in finance, marketing and technology upgradation are categorized into 2 categories of manufacturing and service. For a total of 100 samples and 14 questions, the response is categorized as below 
Table 9: Sector wise response categorization

\begin{tabular}{|l|l|l|l|l|l|l|}
\hline \multicolumn{1}{|c|}{ Age } & \multicolumn{1}{c|}{$\begin{array}{c}\text { Highly } \\
\text { agree }\end{array}$} & $\begin{array}{c}\text { Moderately } \\
\text { agree }\end{array}$ & \multicolumn{1}{c|}{ Undecided } & $\begin{array}{c}\text { Moderately } \\
\text { disagree }\end{array}$ & \multicolumn{1}{c|}{$\begin{array}{c}\text { Highly } \\
\text { disagree }\end{array}$} & \multicolumn{1}{c|}{ Total } \\
\hline Manufacturing & 182 & 242 & 105 & 273 & 178 & 980 \\
\hline Service & 79 & 104 & 45 & 117 & 75 & 420 \\
\hline Total & 261 & 346 & 150 & 390 & 253 & 1400 \\
\hline
\end{tabular}

The overall distribution of responses across Likert five-point scale is as shown below

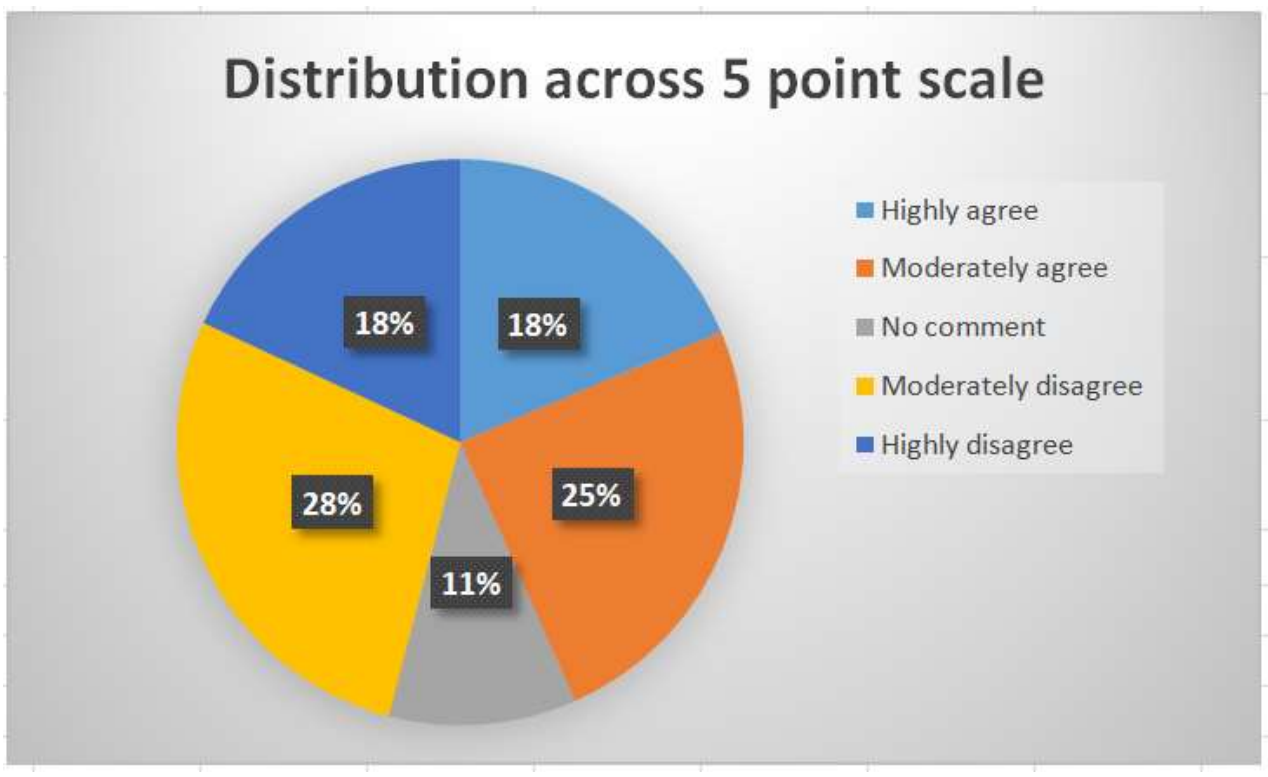

Figure 11: Response distribution across 5 point scale

Categories in 5-point scale are grouped into two categories of agree, disagree. (Highly agree and moderately agree are grouped into agree, Highly disagree and moderately disagree are grouped into disagree)

Table 10: Actual values

\begin{tabular}{|l|l|l|l|}
\hline \multicolumn{1}{|c|}{ Sector } & \multicolumn{1}{c|}{ Agree } & \multicolumn{1}{c|}{ Disagree } & \multicolumn{1}{c|}{ Total } \\
\hline Manufacturing & 424 & 451 & 875 \\
\hline Service & 183 & 192 & 375 \\
\hline Total & 607 & 643 & 1250 \\
\hline
\end{tabular}

In test for homogeneity, the null hypothesis says that distribution of a categorical response variable is the same in each population. In this case, the categorical response variable is views of MMSE units (agree or disagree). The populations are in two sectors of manufacturing and service. The hypothesis 4 can be restated for test of homogeneity as

H0: For each of the two sectors of manufacturing and service, distribution of agree and disagree responses to the question about views of MMSE units are same.

H1: The distribution of the responses is not same.

The expected values for test of homogeneity are calculated before applying chi-square test statistic and find the $\mathrm{p}$ value. 
Table 11: Expected Values

\begin{tabular}{|l|l|l|l|}
\hline \multicolumn{1}{|c|}{ Sector } & \multicolumn{1}{c|}{ Agree } & \multicolumn{1}{c|}{ Disagree } & \multicolumn{1}{c|}{ Total } \\
\hline Manufacturing & $424.9(\mathrm{C} 1)$ & $450.1(\mathrm{C} 2)$ & 875 \\
\hline Service & & & 375 \\
& $182.1(\mathrm{C} 3)$ & $192.9(\mathrm{C} 4)$ & \\
\hline Total & 607 & 643 & 1250 \\
\hline
\end{tabular}

The value for cells (C1- C4) is calculated as follows

$\mathrm{C} 1=607 / 1250 *(875)=424.9$

$\mathrm{C} 2=643 / 1250 *(875)=450.1$

$\mathrm{C} 3=607 / 1250 *(375)=182.1$

$\mathrm{C} 4=643 / 1250 *(375)=192.9$

The Chi-square test statistic is calculated as

$\chi^{2}=\sum \frac{(\text { observed }- \text { expected })^{2}}{\text { expected }}$

$\chi^{2}=0.911502$

The degree of freedom is calculated as $d f=($ rows -1$)($ cols -1$)$ [ Skipping the total rows and columns] , $d f=(2-1)(2-1)=1$ The chi-square distribution with $\mathrm{d} f=1$ is used to find the $\mathrm{p}$ value. 


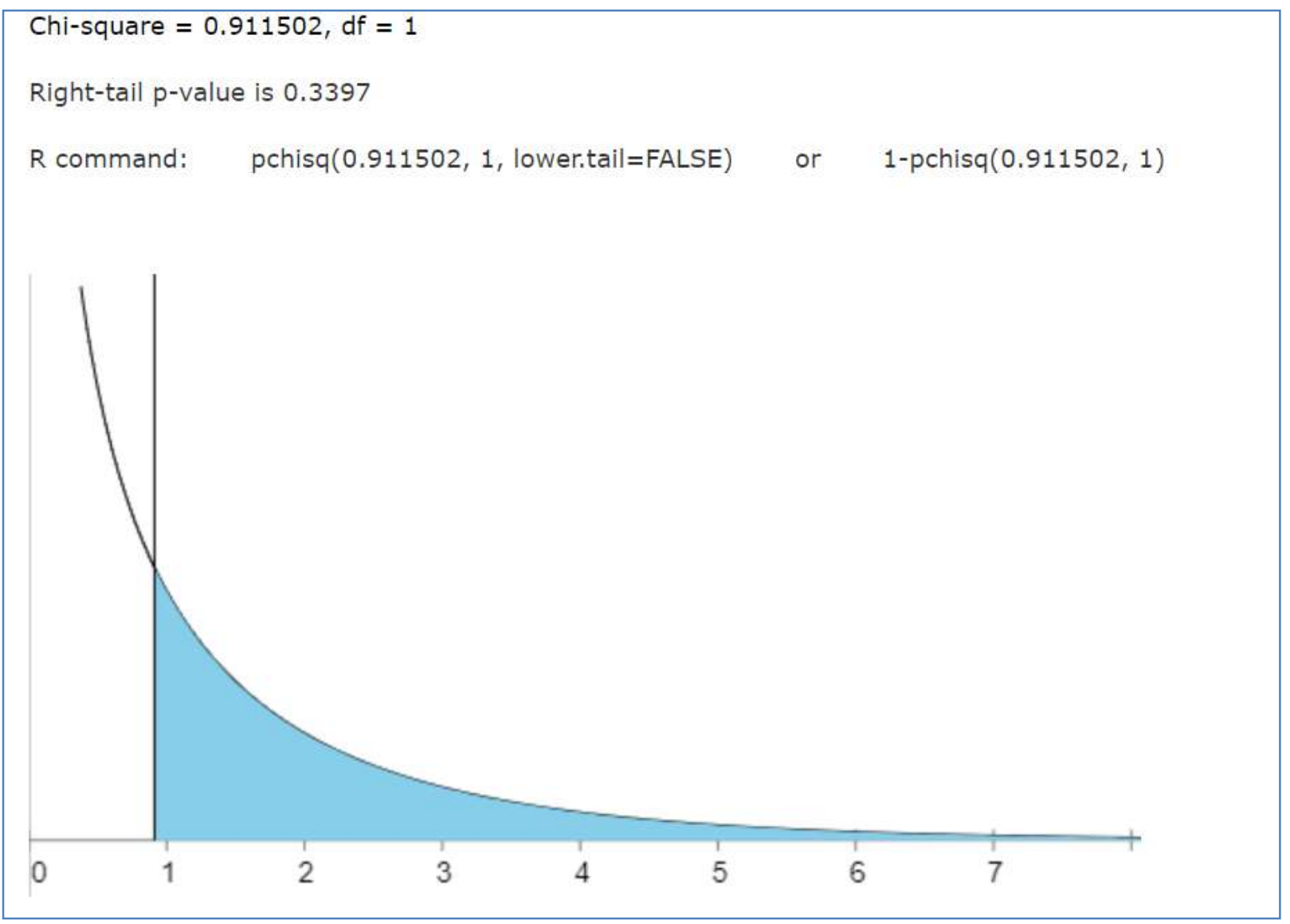

Figure 12: Chi square distribution

The $\mathrm{p}$ value 0.33 is greater than the significant value of 0.05 . Since the $\mathrm{P}$ value is $>0.05$, we cannot reject the null hypothesis and accept "The satisfaction level homogenous across manufacturing and service sector".

\section{FINDINGS \& DISCUSSIONS}

The result from the survey indicates that MSME units in Dharwad are satisfied with the financial provisions but not satisfied with the marketing/promotion and technology upgrade provision of Karnataka Industrial Policy 2014-19. The satisfaction responses are quite homogenous across the manufacturing and service sector. The dissatisfaction level is $46 \%$ in the manufacturing sector and $45 \%$ in the service sector. The dissatisfaction level is $20 \%$ in finance provisions, $67 \%$ in marketing provisions and $75 \%$ in technology upgradation provisions. Thus more schemes in marketing and technology upgrade must be considered in the next 5 years industrial policy.

\section{CONCLUSIONS}

This work analyzed the satisfaction level of different provisions of Karnataka industrial policy 2014-2019 among MSMEs in Dharwad district of Karnataka. The study was conducted in three main area of finance, marketing and technology upgradation, which are the areas creating major hindrances for MSME units. The study infers that satisfaction level in finance provisions were better than that of marketing and technology upgradation provisions. Both service sector and manufacturing sector MSME units displayed the same kind of response. The study highlights the necessity of more schemes in marketing and technology upgradation provisions in the Karnataka industrial policy in next five year plan. 


\section{REFERENCES}

1. Varsha Gupta,Dr J S Saini,Dr Sanjeev Chaddha,"MSME Financing: Growth and Challenges",International Journal for Research in Engineering Application \& Management (IJREAM), Oct 2018

2. Sonia Mukherjee, "Challenges to Indian micro small scale and medium enterprises in the era of globalization",Journal of Global Entrepreneurship Research (2018)

3. A Kumar, Pankaj, "An Empirical Study on Performance of Indian MSME",Asia-Pacific Journal of Management Research and Innovation, 2014.

4. Maumita ChoudhuryMaumita Choudhury,"Struggles of Rural Micro, Small and Medium Enterprises for Bank Finance: Role of District Industries Centres in India",intechopen, 2018

5. Dr .J.ANURADHA,"Problems and Prospects of Micro, Small and Medium Enterprises (Msmes) In India in the Era of Globalization",Journal of Research in Business and Management, Volume $2 \sim$ Issue 6 (2014)

6. Mangipudi Mruthyanjaya Rao,Kdv PRASAD, "IMPACT OF PUBLIC SECTOR BANKS ASSISTANCE TO MSME: A CASE STUDY WITH REFERENCE TO MSMES AND THEIR PERFORMANCE",International Journal of Management (IJM), 2020

7. Anusuya Biswas, Prof. Kalpana Singh, "A REGION-WISE ANALYSIS OF EXPORT PERFORMANCE OF MSME SECTOR IN INDIA AND ITS DETERMINANTS",Journal of Critical Reviews, 2020

8. Smt. Usha C, "TRANSITION TO GST: A STUDY OF MSME SECTOR IN KARNATAKA STATE",The International journal of analytical and experimental modal analysis, 2020

9. Vidit Mohan,Salman Ali, "CHALLENGES FACED BY INDIAN MSMEs IN ADOPTION OF INTERNET MARKETING AND ECOMMERCE ",Academy of Marketing Studies Journal,2019

10. Anjali M Chandak, "Challenges faced by Micro and Small Enterprises in raising bank finance: A special reference to Micro and Small Enterprises in Nagpur",International Journal of Commerce and Management Research,2016

11. Princy Saini, "Study of Micro, Small and Medium Enterprises", Researching Reality Summer Internship 2014

12. Sathish Kotte,Dr. K. Ramulu, "Government Policies and the Development of MSMEs in India",International Journal of Science and Research (IJSR), 2017

13. Harish Tigari, "An Analytical Study on Growth And Performance of Micro Small And Medium Enterprises",IJSART - Volume 4 Issue 6-JUNE 2018.

14. Sajijul Islam,Debdas Ganguly,"Mediating effect of utilisation in the relation between loan services from PSBs and capital formation of MSMEs: a study of Purba and Paschim Medinipur districts of West Bengal",Journal of Global Entrepreneurship Research,2019.

15. Ajeya, G. and Dr. Raghavandra, T S, "Growth performance and problems of msmes in shivamogga district of Karnataka - a study",IJRAMR,2018 

